Relations industrielles

Industrial Relations

\title{
Automation, Manpower and Education, by Jerry M. Rosenberg, Teachers College, Columbia University, Random House, New York, 1966, 179 pages.
}

\section{André Petit}

\section{Volume 22, numéro 4, 1967}

URI : https://id.erudit.org/iderudit/027852ar

DOI : https://doi.org/10.7202/027852ar

Aller au sommaire du numéro

\section{Éditeur(s)}

Département des relations industrielles de l'Université Laval

\section{ISSN}

0034-379X (imprimé)

1703-8138 (numérique)

Découvrir la revue

Citer ce compte rendu

Petit, A. (1967). Compte rendu de [Automation, Manpower and Education, by Jerry M. Rosenberg, Teachers College, Columbia University, Random House, New York, 1966, 179 pages.] Relations industrielles / Industrial Relations, 22(4), 588-589. https://doi.org/10.7202/027852ar

Tous droits réservés @ Département des relations industrielles de l'Université Laval, 1967
Ce document est protégé par la loi sur le droit d'auteur. L’utilisation des services d’Érudit (y compris la reproduction) est assujettie à sa politique d'utilisation que vous pouvez consulter en ligne.

https://apropos.erudit.org/fr/usagers/politique-dutilisation/ 
aboutit à la conclusion que si les travaileurs en général gardent vis-à-vis des changements un esprit ouvert, cette attitude se reflètera dans les ateliers. Dans un milieu social où existe une forte conscience collective, comme c'est le cas dans une localité où une industrie unique mêle intimement le travail et la vie sociale, la résistance aux changements est vive sur ces deux plans. Au contraire, là où les individus se trouvent intégrés dans le processus de croissance d'une société ò économie diversifiée, la résistance aux innovations sera vraisemblablement moins grande. L'attitude des individus en face des changements est conditionnée par leurs attentes personnelles et celles- $\mathrm{Ci}$ a leur tour vorient selon l'âge, le sexe, l'origine, la religion et autres particularités individuelles et sociales. Le facteur qui a le plus d'influence sur l'attitude du travailleur est la mesure dans laquelle il se sentira ossuré d'une sécurité économique. De même il sera, plus disposé à accepter des innovations qui ne bouleverseront pas sa vie professionnelle ou ne viendront pas se mettre en travers de ses attentes que celles dont i) croindra qu'elles ne le fassent.

Les chapitres de ce livre présentent les principaux résultats obtenus dans la connaissance des réactions ouvrières aux changements techniques. Ils considèrent successivement l'ouvrier comme exécutant, comme membre d'une organisation et de systèmes de relations sociales, comme salarié, c'est-àdire comme soumis à un pouvoir de décision économique, enfin comme membre de collectivités étrangères au milieu du travail: famille, groupe ethnique, ville ou quartier.

L'étude aboutit à la conclusion qu'un chongement technique ne peut être envisagé comme un événement isolé. De même, l'attitude de l'ouvrier à son égard sera le résultat d'un ensemble complexe d'influences économiques, politiques et sociales. Prenant en considération les faits passés pour juger de l'évolution future, I'auteur émet I'opinion que les syndicats chercheront ò prendre une plus grande part à la prise des décisions à tous les niveaux, et à assurer aux ouvriers de plus nombreuses possibilités de donner expression à leurs facultés créatrices. A son avis, les travailleurs aspirent ò trouver dans l'accomplissement de leurs tâches l'occasion de satisfaire dans une mesure substantielle leur désir de s'exprimer. Une fois ces aspirations exaucées, syndicats et individus seront plus enclins à considérer dons une optique plus pragmatique et fonctionnelle qu'idéologique les problèmes résultant des changements techniques.

Pierre DIONNE
Automation, Monpower and Education, by Jerry $M$. Rosenberg, Teachers College, Columbio University, Random House, New York, 1966, 179 pages

L'impact de l'automation sur les différentes sociétés a fait l'objet de nombreux écrits $M$. Jerry $M$. Rosenberg ajoute un élément intéressant lorsqu'il offirme qu'à cette révolution par l'automation devra peut-être succéder une révolution par l'éducation.

II s'intéresse donc dans ce livre, non aux avantages matériels que peut susciter l'automation, mais plutôt à son effet sur les gens. A cet égard, les retards que peut accumuler un système éducationnel sont d'une importance prépondérante et l'auteur consacre l'un des premiers chapitres cux responsabilités nouvelles des éducateurs face ò I'automation. II fait ensuite le point sur une façon meilleure d'utiliser nos ressources en main-d'oeuvre et tente de clarifier certains malentendus ou sujet de l'automation.

Le système éducationnel doit fournir à tous, les opportunités de remplir les nouvelles positions et de faire face oux nouvelles situctions et ceci dans tous les domaines. Pour que la montée des effectifs scolaires de la nation ne conduise pas à une impasse, il faut que le systèrne entier soit repensé et renouvelé.

Le paradoxe actuel au sujet de la maind'oeuvre est le suivant: un nombre grandissant de personnes ò la recherche d'un emploi et un nombre grandissant d'ernplois qui derneurent libres. On en conclu rapidement à la nécessité de préparer les étudiants et même les travailleurs actuels à remplir adéquatement les emplois de demain. L'auteur nous indique plusieurs de ces nouveaux domaines. II s'attarde ensuite sur l'impact socio-psychologique de l'automation. II y rapporte les opinions de grands spécialistes, tels George Gallup, Pierre Naville, Dr Nathan Cohen, William Faunce et d'autres. Pour lever les inquiétudes et écarter les fausses conceptions, l'auteur propose que soient donnés des cours dont le sujet serait l'automation sous tous ses aspects.

Dans le processus actuel des transformations, quelque chose a changé aux EtatsUnis: les différents secteurs sont devenus beaucoup plus sensibles au problème du chômage et aux pertes qu'il entrcîne. Nous retrouvons dans cette publication une description des efforts des gouvernements, des industries et des associations de travailleurs, pour améliorer la situation. II y a insistance sur les nouvelles méthodes employées dans le domaine du personnel: formation, réen- 
troînement, diminution de la durée du travail, mise à la retraite accélérée, etc.

L'auteur conclue en posant une série de questions auxquelles il répond brièvement. Les unes portent sur ce qu'on peut ou doit ottendre du gouvernement, de l'industrie et des syndicats. Les autres portent sur les responsabilités nouvelles de la communauté, des écoles et des éducateurs.

D'une lecture relativement focile, ce volume offre à tous l'opportunité de se familiariser rapidement avec ces questions brûlontes d'actualité.

\section{André PETIT}

The Technocrates, Prophets of Automation, by Henry Elsner, Jr., Syrocuse University Press, Syracuse, New York, 1967, \$10.00.

During the nineteen thirties, a movement known as technocracy flourished for several years and then, as a comet, moved out of sight. It is recalled now as an episode of the depression years.

Its present importance, however, is its message as prophetic of current discussions of automation.

This volume fills the need of an account of the sources, development and disintegration of technocracy.

It is to be recognized that contures of technocracy, similar to those of automation, cre described with differing limitations by numerous commentators.

Since technocracy was the child of the Great Depression, its emphasis was upon the predominance of the machine, sharp criticisms of the price system, and its high evaluation of engineers, technicians and other scientific personnel.

Its critique of the economic organization was not matched by constructive proposal as - remedy.

The impractal substitution of a standard of value based on energy units to replace the prevalant monetary system led to the disintegration of the technocratic idea, aided by improving economic conditions including the lessening of unemployment.

We are not yet in a position to assess the diverse controversies about either the " good 》 or " evil » consequences of automation. Economic conditions act as impressive guides
Already, the forebodings of the more extreme cassandras with respect to automation's dire effects both present and potential, are being modified. This is true, ot least for the United States, where the Commission on Technology, Automation and Economic Progress found a more favourable economic situation at the end of its investigation, than that which confronted it as the commencement of its work.

Professor Elsner, of the faculty of Villanova University, Pennsylvania, was a been age technocrat, and his participation in its octivities afforded him first hand information of its leading figures, and the complex, often contending organizations which were part of its history.

Of special interest is the valuable bibliography of books, pamphlets, periodicals, and fugitive literature on the subject matter of the book.

For those interested in a phase of the critical attacks and proposed remedies for the price system, and the role of engineers, technicians, and other scientists in our industrial society, this book will shed light on an almost forgotten segment.

\section{Benjamin S. KIRSH}

Challenges to Collective Bargaining, by Lloyd Ulman, Editor, Prentice-Hall, Inc., $\$ 4.95$ clothbound, $\$ 1.95$ Spectrum paperbound, 1967, 192 pages.

This volume contains the papers presented at the American Assembly, at Arden House, the Harriman Campus of Columbia University in October 1966

The scope of the conference may be found in the enumeration of the several subjects under discussion.

After the editor's introduction on the problems in Historic Context, the topics include stability and change in the structure of collective bargaining; pensions, health and welfare plans; collective bargaining in the public sector; the employment and training of minorities; labor relations law; wageprice policy and alternatives; two views of collective bargaining.

Each of chapters is outhored by a leading authority in that particular field. The range of contempary conflicts and problems which the technological age present, not only to management and labor but the public as well, are thoughtfully considered. 